\title{
Use of a Mycoplasma suis-PCR protocol for screening a population of captive peccaries (Tayassu tajacu and Tayassu pecari)
}

Uso de um protocolo de PCR para a detecção de Mycoplasma suis para avaliação de uma população de catetos e queixadas de cativeiro (Tayassu tajacu and Tayassu pecari)

Rafael Felipe da Costa Vieira ${ }^{1 *}$; Marcelo Beltrão Molento ${ }^{2}$; Ana Marcia Sa Guimarães ${ }^{3}$; Andrea Pires dos Santos ${ }^{3}$; Marcelo Bonat ${ }^{4}$; Manoel Lucas Javorouski ${ }^{4}$; Luciene Popp ${ }^{4}$; Leonilda Correia dos Santos 5 ; Wanderlei Moraes Zalmir Silvino Cubas ${ }^{5}$; Thállitha Samih Wischral Jayme Vieira'; Odilon Vidotto ${ }^{1}$; Ivan Roque Barros Filho²; Alexander Welker Biondo' ${ }^{2}$ Joanne Belle Messick ${ }^{3}$

${ }^{1}$ Departamento de Medicina Veterinária Preventiva, Universidade Estadual de Londrina - UEL

${ }^{2}$ Departamento de Medicina Veterinária, Universidade Federal do Paraná - UFPR

${ }^{3}$ Department of Comparative Pathobiology, School of Veterinary Medicine, Purdue University

${ }^{4}$ Zoológico Municipal de Curitiba, Prefeitura de Curitiba

${ }^{5}$ Refúgio Biológico Bela Vista, Itaipu Binacional

Received June 24, 2010

Accepted November 5, 2010

\begin{abstract}
Mycoplasma suis is a hemotropic bacteria of red blood cells and the causative agent of swine eperythrozoonosis. Diagnosis of infection may be reached by direct examination of blood smears; however, the use of polymerase chain reaction (PCR) of the 16S RNA gene of $M$. suis improves the sensitivity and specificity of detection. The aim of this study was to screen peccaries (Tayassu tajacu and T. pecari) for $M$. suis infection using a specific conventional PCR. A total of 28 blood samples from captive collared and white-lipped peccaries were collected, DNA extracted and a specific $M$. suis PCR assay performed. All samples were negatives by both blood smear examination and PCR testing. To verify the presence of amplifiable DNA, PCR for beta-actin gene was performed in all samples. This study was part of an active surveillance program, which is crucial for monitoring animal health status, particularly in wildlife species.

Keywords: Eperythrozoonosis, collared peccaries (Tayassu tajacu), white-lipped peccaries (Tayassu pecari), wild pigs.

\section{Resumo}

Mycoplasma suis é uma bactéria hemotrópica dos eritrócitos e é o agente causador da eperitrozoonose suína. O diagnóstico da infecção pode ser realizado pelo exame direto de esfregaços sanguíneos; entretanto, o uso da reação em cadeia da polimerase (PCR) baseada no gene 16S RNA de $M$. suis aumenta a sensibilidade e especificidade da detecçáo. O objetivo deste estudo foi avaliar catetos e queixadas (Tayassu tajacu e T. pecari) para a infecção por M. suis, utilizando PCR convencional específico. Um total de 28 amostras de sangue de catetos e queixadas de cativeiro foram coletadas, o DNA foi extraído e a PCR específica para a detecção de M. suis realizada. Todas as amostras foram negativas pelo esfregaço sanguíneo e PCR. Para verificar a presença de DNA amplificável, PCR para o gene da beta actina foi realizada em todas as amostras. Este estudo foi parte de um programa de vigilância ativa, o qual é crucial para o monitoramento do estado de saúde animal, particularmente em espécies selvagens.
\end{abstract}

Palavras-chave: Eperitrozoonose, cateto (Tayassu tajacu), queixada (Tayassu pecari), porcos selvagens.

\footnotetext{
${ }^{*}$ Corresponding author: Rafael Felipe da Costa Vieira

Programa de Pós-Graduaçáo em Ciência Animal, Departamento de Medicina

Veterinária Preventiva, Universidade Estadual de Londrina - UEL,

Pr 445, Km 380, CEP 86051-990, Londrina - PR, Brazil;

e-mail: vieirarfc@gmail.com
} 
Mycoplasma suis (formerly Eperythrozoon suis), the causative agent of eperythrozoonosis in swine, is a small pleomorphic bacterium that attaches to porcine red blood cells and it is known as hemotropic mycoplasma (hemoplasma) (MESSICK, 2004). Two different forms of the disease have been described in domestic pigs: an acute form with severe hemolytic anemia and a chronic stage without clear hematological abnormalities. In commercial pig farms, the chronic form of infection is most commonly found, possibly due to the use of tetracycline in the food. Chronically infected sows may show reproductive alterations and feeder pigs may present with decreased weight gain. The acute form of infection, however, is mostly seen following immunosuppressive events or splenectomy. Common clinical signs include anorexia, weakness, depression, anemia, icterus and fever (HENRY, 1979; HEINRITZI, 1999).

Mycoplasma suis has never been successfully cultivated in vitro. Although the diagnosis of $M$. suis infection in pigs has been based on microscopic observation of organisms attached to red blood cells, this technique is neither sensitive nor specific, particularly in chronic stages of the disease. Amplification of $M$. suis $16 \mathrm{~S}$ rRNA gene by polymerase chain reaction (PCR) has reportedly shown a higher specificity and sensitivity, even in chronic infections (MESSICK, 2004).

Mycoplasma suis has been detected in domestic pigs throughout the world, including Brazil (GUIMARÁES et al., 2007; HOELZLE et al., 2007). Domestic pigs and peccaries belong to the same order Artiodactyla, but to distinct families Suidae and Tayassuidae, respectively. A single report documenting Eperythrozoon spp. infection in peccaries (Tayassu pecari) in Texas was based on the observation of inclusion-like bacteria attached to red blood cells by light microscopic examination of blood smears stained with Diff-Quick' (HANNON et al., 1985). Therefore, we hypothesized that $M$. suis may be able to infect wild pigs from the Tayassuidae family, including the collared peccary (T. tajacu) and white-lipped peccary (T. pecari), which are widely found in Brazil (FURTADO; KASHIVAKURA, 2007). The aim of this study was to screen peccaries for $M$. suis infection using two methods: blood smear examination and a species-specific PCR assay based on 16S rRNA gene of this microorganism.

Anticoagulated (EDTA) blood samples were taken from six captive collared peccaries at the Bela Vista Sanctuary, Itaipu Binacional, Foz do Iguaçu, Paraná State, Brazil, and six whitelipped peccaries and 16 collared peccaries at the Curitiba Zoo, Curitiba, Paraná State, Southern Brazil, under specific chemical restraint (ketamine hydrochloride 10\%, xylazine hydrochloride $2 \%$ and atropine sulfate $1 \%$ ), and stored at $4{ }^{\circ} \mathrm{C}$ for two hours until hematological analyses. Thereafter, samples were stored at $-20{ }^{\circ} \mathrm{C}$ until molecular procedures. Animal and laboratory procedures were approved and performed in accordance with the regulations of the Instituto Brasileiro do Meio Ambiente e Recursos Renováveis (IBAMA, 2010).

Blood smears were prepared and stained by a quick Romanovskytype stain (Panótico Rápido’, Laborclin’, Pinhais, Paraná State, Brazil). They were examined using light microscopy at high magnification ( $40 \times$ and $100 \times$ objective lens). DNA was extracted from $200 \mu \mathrm{L}$ blood using a commercially available kit according to the manufacturer's instructions (Ilustra ${ }^{\mathrm{TM}} \mathrm{GFX}^{\mathrm{TM}}$ Genomic
Blood DNA Purification Kit, GE Healthcare, Buckinghamshire, UK). To ensure successful DNA extraction and absence of PCR inhibitors, a PCR for the housekeeping gene, $\beta$-actin, was performed as previously described (GUIMARÁES et al., 2007). All samples were initially screened by PCR using a bacterial universal primer set (MESSICK et al., 1998). A PCR for the detection of $837 \mathrm{bp}$ fragment of the 16S rRNA gene of the $M$. suis was then performed as previously described (GUIMARÃES et al., 2007). All reactions were performed using DNA from an infected domestic pig and water as positive and negative controls, respectively.

Direct examinations of blood smears from all animals were negative for Mycoplasma-like infection. Although housekeeping gene DNA was successfully amplified, all 28 peccary samples were negative by PCR for Mycoplasma spp. infection.

Negative results found in both methods may not ensure that animals are free of $M$. suis infection. Although the examination of blood smears is not a sensitive method, 5/7 (71\%) of the blood samples from peccaries in Texas were positive by blood smears examination for Eperythrozoon spp., but PCR amplification was not performed and it is unknown whether the organisms seen in blood smears were $M$. suis or a not-yet-described hemoplasma species. In another study, the examination of 120 blood smears collected from peccaries revealed no cases of parasitemia (HANNON et al., 1985). On the other hand, if the prevalence of $M$. suis infection is low $(<1 \%)$, it is possible that too few animals were sampled to confidently find infected animals, even by PCR. It is also possible that peccaries are infected by other hemoplasma species, which were not be amplified by the primer set used in this study. In a study of pigs from commercial farms in southern Brazil the prevalence of $M$. suis infection was $18 \%$ by PCR, however when Southern Blot technique was used the prevalence increased to $33 \%$ (GUIMARÁES et al., 2007). Thus, it is important to mention that data obtained using only conventional PCR is limited, and the use of other more sensitive techniques combined is recommended.

Active surveillance programs are crucial for monitoring animal health status, particularly in wild species. These animals may serve as sentinels for infectious agents, and since commercial farms of peccaries are becoming an area of investment, screening these animals to avoid disease spread and economic losses is imperative. In addition, the white-lipped peccary is listed in Appendix II of the Convention on International Trade in Endangered Species of Wild Fauna and Flora (CITES, 2010). Thus, sustained efforts are needed to protect the health and well-being of these animals.

\section{References}

CITES. Apêndice II da Convençáo sobre o comércio internacional das espécies da fauna e da flora selvagens ameaçadas de extinçáo. Disponível em: <http://www.cites.org/eng/app/appendices.shtml>. Acesso em: 17 jun. 2010.

FURTADO, M. M.; KASHIVAKURA, C. K. Artiodactyla - Tayassuidae e Suidae (Cateto, Queixada, Javali) In: CUBAS, Z. S., SILVA, J. C. R.; CATÃO-DIAS, J. L. (Ed.). Tratado de animais silvestres: medicina veterinária. São Paulo: Roca, 2007. p. 615- 629. 
GUIMARÃES, A. M. S. et al. Exploratory study of Mycoplasma suis (Eperythrozoon suis) on four commercial pig farms in southern Brazil. Veterinary Record, v. 160, n. 2, p. 50-53, 2007.

HANNON, P. G. et al. Eperythrozoon in Captive Juvenile Collared Peccaries in Texas. Journal of Wildlife Diseases, v. 21, n. 4, p. 439-440, 1985.

HEINRITZI, K. Eperythrozoonosis. In: STRAW, B. E. et al. (Ed). Diseases of swine. $8^{\text {th }}$ ed. Ames: Iowa State University Press, 1999. p. 413-418.

HENRY, S. C. Clinical observations on eperythrozoonosis. Journal of the American Veterinary Medical Association, v. 174, n. 6, p. 601-603, 1979.

HOELZLE, L. E. et al. First LightCycler real-time PCR assay for the quantitative detection of Mycoplasma suis in clinical samples. Journal of Microbiological Methods, v. 70, n. 2, p. 346-354, 2007.
INSTITUTO BRASILEIRO DE MEIO AMBIENTE E DE RECURSOS RENOVÁVEIS - IBAMA. Lista oficial do Instituto Brasileiro de Meio Ambiente e de Recursos Renováveis (IBAMA) de espécies da fauna brasileira ameaçadas. Disponível em: <http:// www.mma.gov.br/port/sbf/fauna/index.cfm>. Acesso em: 17 jun. 2010.

MESSICK, J. B. Hemotrophic mycoplasmas (hemoplasmas): a review and new insights into pathogenic potencial. Veterinary Clinical Pathology, v. 33, n. 1, p. 2-13, 2004.

MESSICK, J. B.; BERENT, L. M.; COOPER, S. K. Development and evaluation of a PCR-based assay for detection of Haemobartonella felis in cats and differentiation of $H$. felis from related bacteria by restriction fragment length polymorphism analysis. Journal of Clinical Microbiology, v. 36, n. 2, p. 462-466, 1998. 